\title{
Examining the Impact of Leader-Member Exchange on Perceptions of Organizational Justice: The Mediating Role of Perceptions of Organizational Politics
}

\author{
Arun Aggarwal', Jatin Goyal², Kamrunnisha Nobi ${ }^{3}$ \\ ${ }^{1}$ Doctoral Research Centre, Chitkara Business School, Chitkara University, Rajpura, India \\ ${ }^{2}$ University School of Applied Management, Punjabi University, Patiala, India \\ ${ }^{3}$ Mata Sahib Kaur Girls College, Talwandi Sabo, Punjabi University, Patiala, India \\ Email: arunaggarwal.mba@gmail.com, jatin2goyal@gmail.com, kamrunnishaibm@gmail.com
}

How to cite this paper: Aggarwal, A., Goyal, J. and Nobi, K. (2018) Examining the Impact of Leader-Member Exchange on Perceptions of Organizational Justice: The Mediating Role of Perceptions of Organizational Politics. Theoretical Economics Letters, 8, 2308-2329.

https://doi.org/10.4236/tel.2018.811150

Received: June 4, 2018

Accepted: August 12, 2018

Published: August 15, 2018

Copyright $\odot 2018$ by authors and Scientific Research Publishing Inc. This work is licensed under the Creative Commons Attribution International License (CC BY 4.0).

http://creativecommons.org/licenses/by/4.0/

c) (i) Open Access

\begin{abstract}
The present study examines the mediating role of perceptions of organizational politics on the relationship between leader-member exchange and perceptions of organizational justice. With the help of multi-stage random sampling technique, data was collected from 493 faculty members who were working in public sector universities of Punjab. Structural Equation Modeling (SEM) was applied to test the proposed hypothesized relationships. Results of the structural equation modeling analysis demonstrated that employees who are part of in-group have higher levels of perceptions of organizational politics but lower levels of perceptions of organizational justice. Furthermore, employee who perceives high degree of organizational politics has shown lower levels of perceptions of organizational justice. Results of the study postulated that for more positive perceptions of organizational justice among the employees a leader should develop a high quality relationship with more employees by limiting the usage of more political behavior within the organization. This study is one of its type in Indian context as we find no empirical evidence which examines the effect of quality of leader-member exchange relationship on the perceptions of organizational justice which is being mediated through the perceptions of organizational politics of faculty members.
\end{abstract}

\section{Keywords}

Leader-Member Exchange, Perceptions of Organizational Politics,

Perceptions of Organizational Justice 


\section{Introduction}

In this competitive era of global business scenario, which is characterized by complexities and volatility, organizations are under constant pressure to retain and attract talented employees who can play a vital role in acquiring and maintaining the competitive advantage of the organization. In context of this, different researchers have acknowledged the importance of perceptions of organizational justice as it has various individual and organizational consequences such as, organizational commitment [1] [2] [3] [4]; withdrawal behavior [5] [6]; job satisfaction [4] [7]; trust [2]; turnover intension [8] [9] [10] [11] [12]; job performance [13] [14] [15] and organizational citizenship behavior [16] [17] [18] [19] [20]. For instance, previous empirical results have shown that employees perceptions of fair treatment within the organization [21], their perceptions of fairness in the enactment of procedures [13] and their motivation to have fair consequences [22] effect their work performance to a greater extent. As a result of these findings, several human resource practices are being reviewed and re-examined [23] [24] [25]. The assumptions of social exchange theory play a vital role in explaining many of these results [26]. More specifically, it is believed that perceptions of organizational justice (particularly interactional justice and procedural justice) help in initial formations of dyadic relationship [27] [28]. Furthermore, this perceived fairness by an employee is reciprocated in the way of favorable workplace behavior and attitude [29]. Furthermore, it has also been manifested that the perceptions of organizational justice are not only affected by the quality of leader-member exchange [17] [30] [31] [32] but also by the degree of one's perceptions of organizational politics [33] [34] [35] [36] [37]. Therefore, it is important to know how and why the perceptions of employees vary in respect of organizational justice despite providing same working environment as these perceptions have both individual and organizational consequences.

The purpose of the present study is to examine the mediating role of perceptions of organizational politics on the relationship between the quality of leader-member exchange and four dimensions of perceptions of organizational justice. The results of the present study contribute immensely to the existing literature. As the result of the present study renders that in-group member perceives high level of organizational politics as compared to employees who are part of out-group members. Till now, only one study has shown this type of results [38]. Therefore, the results contribute to the present literature by postulating the importance of individual differences in perceiving the political environment. Apart from this, results also manifest that perceptions of organizational politics have negative relationship with three types of perceptions of organizational justice (procedural, distributive and informational justice) whereas interactional justice was positively associated with perceptions of organizational politics. This study endeavored a new insight on how leader-member exchange perspectives and attributions contribute in eliciting negative affective and cognitive responses to the perceptions of political environment. The study argues that quality of LMX en- 
hance one's understanding of these organizational reactions and processes in a political environment. Therefore, leader plays a vital role in molding the perceptions of employees regarding organizational politics.

The present study is organized in a systematic manner in which the researcher first talks about the introduction part. In the introduction section, a brief description regarding the topic is provided along with the theoretical contribution of this research paper. The second section is devoted towards literature review and the research gap. Then detailed information is given regarding participants and procedure used to collect the data. After that detailed information is given pertaining to research instrument used to measure the quality of leader-member exchange, perceptions of organizational justice and perceptions of organizational politics. The next section is devoted to data analysis and results. After that, a detailed discussion is given pertaining to the results of the present study and their practical implications along with their limitations is also discussed.

\section{Review of Literature}

\subsection{Leader-Member Exchange and Perceptions of Organizational Politics}

The perception of organizational politics is pervasive in organizational setting and it has been linked with various organizational behavioral and attitudinal consequences [39]. Ferris, G. R., \& Kacmar, K. M. [40] termed the perceptions of organizational politics as a state of mind which is subjective experience of an individual. Similarly, the quality of leader-member exchange relationship is a subjective aspect of similarity among leader and subordinates. So, the quality of dyadic relationship among subordinate and leader can affect the perceptions of employees regarding organizational politics. Employees who have lower quality relationships with their supervisor perceive that the in-group members receive more rewards, more chances of interaction with their supervisor and higher job performance not because of objectivity but because of political factors [41]. So, individuals who are part of out-group are more likely to have a higher level of perceptions of organizational politics as compared to individuals who are part of high quality relationship (in-group). Valle, et al. [42] and [40] also supported this by demonstrating a significant inverse relationship between the perceptions of organizational politics and the quality of leader-member exchange. So, out-group members might perceive that in-group members are given favor based on political factor rather than objective factors [40] [41]. On the contrary, Andrews, M. C. \& Kacmar, K. M. [38] demonstrated a positive relationship between the perceptions of organizational politics and the quality of leader-member exchange. They suggested that individual who is part of high quality relationship will have "in-the-know" regarding the machinations of organizational politics. On the contrary, researchers like Valle et al. [40] [42] [43] have demonstrated a significant negative relationship between perceptions of organizational politics and the leader-member exchange relationship. Ferris, G. R., 
Perrewé, P. L., \& Douglas, C. [44] proposed that the perceptions of in-group members regarding organizational politics will be less as they enjoy more control over situations than out-group members. As the quality of leader-member exchange is relational in nature, it is expected that individuals who either having high political skills or are part of high quality relationship will be having same type of organizational outcomes. Previous research has associated leader-member exchange to promotions [45], performance rating [46] [47] [48] and alliance formation [49]. These all organizational outcomes are also the outcomes of high political skilled individuals [50]. So, it makes no major changes in the organizational outcome if either you are part of in-group member or you have high political skills. However, individuals who are not part of high quality relationship should possess these high political skills in order to have desired outcomes as that of high-quality members enjoy.

H1: Leader-member exchange is negatively related with perceptions of organizational politics.

\subsection{Perceptions of Organizational Politics and Perceptions of Organizational Justice}

Organizational justice refers to an individual's perception or evaluation of the appropriateness of some process or outcome [51]. Organizational justice describes the perception of the fairness of distribution, processes, and personal interactions in the workplace [52] [53]. Thus, perceptions of organizational justice can be defined as "the degree to which individuals believe the outcomes they receive and the way they are treated within organizations are fair, equitable, and in line with expected moral and ethical standards" [54], which have been used to examine different pertinent organizational behaviors and attitudes [2] [55] [56]. In organizational research, organizational justice is conceived as social construct [57] [58] that is, perceptions of organizational justice are not developed or originated in isolation [51]. It means that an action is considered as "just" if majority of individuals are perceiving it as fair or just [51]. That is, "what is fair" is extracted from previous research associating subjective perception of justice with objective aspects which are being considered while making an organizational decision [56]. Previous research has demonstrated that an individual's perception of organizational politics affects their perceptions regarding organizational justice [33] [34] [35] [36] [37]. Byrne, Z. [35] tested the proposition that interactional and procedural fairness mitigates the negative effects of perceived organizational politics on organizational citizenship behavior, turnover intentions and in-role job performance. Results of the study revealed that perceived high levels of procedural justice significantly moderate the relationship between covert political behavior (go along to get ahead) and turnover intentions but not with general political behavior (overt) and turnover intentions. However, the relationship between covert behavior and interactional justice was in opposite direction. Neither the perceptions of interactional nor the perceptions of procedural 
justice moderated the perceptions of two types of organizational politics on $\mathrm{OBC}$ beneficial to supervisors and supervisors rated job performance. Study finally depicted that both interactional and procedural justice had moderating effects on covert but not on overt political behavior. Amah, O., \& Okafor, C. [36] studied the interactive effects of perceptions of organizational politics on the relationship between organizational justice, organizational support and job satisfaction. Results indicated that job satisfaction had significant positive relationship with organizational justice and organizational support and had a negative relationship with organizational politics. Results also showed that organizational politics interact with both procedural and interactional justice but not with distributive justice to predict job satisfaction and further this interaction was significant for participant who had high perceptions of organizational politics than those with low perceptions.

H2: Perceptions of organizational politics is negatively related with four dimensions of perceptions of organizational justice.

\subsection{Leader-Member Exchange and Perceptions of Organizational Justice}

The relationship between the quality of leader-member exchange and employee's perception regarding organizational justice has been well established by different researchers in prior empirical work. Previous research suggested that employee's perceptions regarding organizational justice is affected by the process of leader-member exchange [30], such that in-group members perceptions regarding fairness will be more as compared to employees who are not part of in-group (out-group) members [17] [31] [32]. Furthermore, [59] found that employees who are part of high quality relationships (in-group members) receive higher ratings from their supervisors as compared to employees who are members of out-group members. The reason for such type of high rating despite the fact that whether these members are performing well or not might be that the supervisor want to protect their relationship. Research has found that if the allocations of resources within the organization are perceived to be fair then it will contribute in positive social-exchange relationships [60].

H3: Leader-member exchange is positively related with four dimensions of perceptions of organizational justice.

\subsection{Mediating Role of Perceptions of Organizational Politics}

On the basis of above mentioned relationships, it can be purposed that high quality relationship among employee and employees leads to higher levels of perceptions of organizational justice. But the mechanism through which the quality of leader-member exchange had an influence on the perceptions of employees regarding organizational justice has not been well established. So, another objective of the present study to examine the mechanism which affects the relationship between leader-member exchange and perceptions of organiza- 
tional justice. The scrutiny of above literature revealed that the quality of leader-member exchange and perceptions of organizational politics had a negative relationship [40] [41] [42] [43] [44] [50]. Furthermore, high perceptions of organizational politics lead to lower levels of perceptions of organizational justice among the employees [33] [34] [35] [36] [37]. Therefore, in the present study researcher examines the mediating role of perceptions of organizational politics on the relationship between leader-member exchange and perceptions of organizational justice as there are very few studies which examines the mediating role of perceptions of organizational politics [30] [42] [61]. In line with results of the study by Valle, M. \& Perrewé, P. L. [42], the present study also try to find out what are the factors that affects the employee's perceptions of organizational politics and what are its consequences. Valle, M. \& Perrewé, P. L. [42] examined the antecedents and consequences of perceptions of organizational politics. Results of the multiple regression and moderated regression analysis revealed that defensive/reactive behavior by the employees aggravate the negative effects of perceptions of organizational politics on different outcomes such as job satisfaction, job stress and turnover intensions. Furthermore, results of the study depicted that work/job environmental factors (job autonomy, skill variety, feedback, supervisor/co-worker influence) explained more variance in perceptions of employees pertaining to organizational politics rather than organizational influence (centralization, formalization, hierarchical level and span of control) or personal factors (need for power or locus of control). An interesting finding of the study was significant negative relationship between internal locus of control and perceptions of organizational politics, such that employees who have internal locus of control will have high levels of perceptions of organizational politics. Finally, results of the study demonstrated that perceptions of organizational politics mediate the relationship between all the proposed antecedents and consequences.

H4a: Perceptions of organizational politics mediates the relationship between leader-member exchange and perceptions of procedural justice.

H4b: Perceptions of organizational politics mediates the relationship between leader-member exchange and perceptions of distributive justice.

H4c: Perceptions of organizational politics mediates the relationship between leader-member exchange and perceptions of interpersonal justice.

H4d: Perceptions of organizational politics mediates the relationship between leader-member exchange and perceptions of informational justice.

The scrutiny of the above literature revealed that till now there is not much clarity on how perceptions of organizational politics is affected by individual difference and how it further affects the perceptions of organizational justice. As different authors have purposed different relationships. Apart from this, till now there is no single study which has been conducted in Indian context that too in educational sector. Therefore, this will be a future avenue for the researcher to consider this research as base and try to explore the factors that affects the perceptions of organizational politics which further has many individual and organizational consequences in Indian scenario. 
The proposed conceptual models (Figure 1) depict the relationship between leader-member exchange, perceptions of organizational politics and perceptions of organizational justice. The model not only shows the direct relationship between leader-member exchange and perceptions of organizational justice but also shows the mediating role of perceptions of organizational politics on the relationship between leader-member exchange and perceptions of organizational justice.

\section{Method}

\subsection{Participants and Procedures}

In this cross sectional study, we used multistage random sampling technique to collect the data from faculty members working at public universities which are situated in Punjab. Questionnaire was distributed to 1253 out of which 523 questionnaires were returned with a percentage return rate of 41.74 percentage. Furthermore, out of this 523 questionnaire 30 questionnaires were dropped for final analysis either due to the reason of missing data or unengaged response pattern. So, finally 493 questionnaires were used for the final analysis out of which 239 (48.5\%) respondents were male and 254 (51.5\%) were females. The age of the subjects were in the range of 24 to 74 years, which a mean age of 36 years. In term of institute in which these faculty members were working, the proportion of respondents was quite uniform with 128 respondents from Punjabi University Patiala, 117 from Guru Nanak Dev University, 132 from Punjab Agricultural University and 116 from Panjab University Chandigarh. When it comes to the designation of the subject, most of the employees were falling in the category of assistant professor (76.9\%), followed by Associate professor (12.00\%) and Professors (11.2\%). In terms of educational qualification, there were 96 respondents who have master's degree, 52 respondents have done M. Phil and 345 respondents have doctorate degree. Out of 493 respondents, 245 respondents were having experience of 1 to 8 years and 248 respondents have job experience

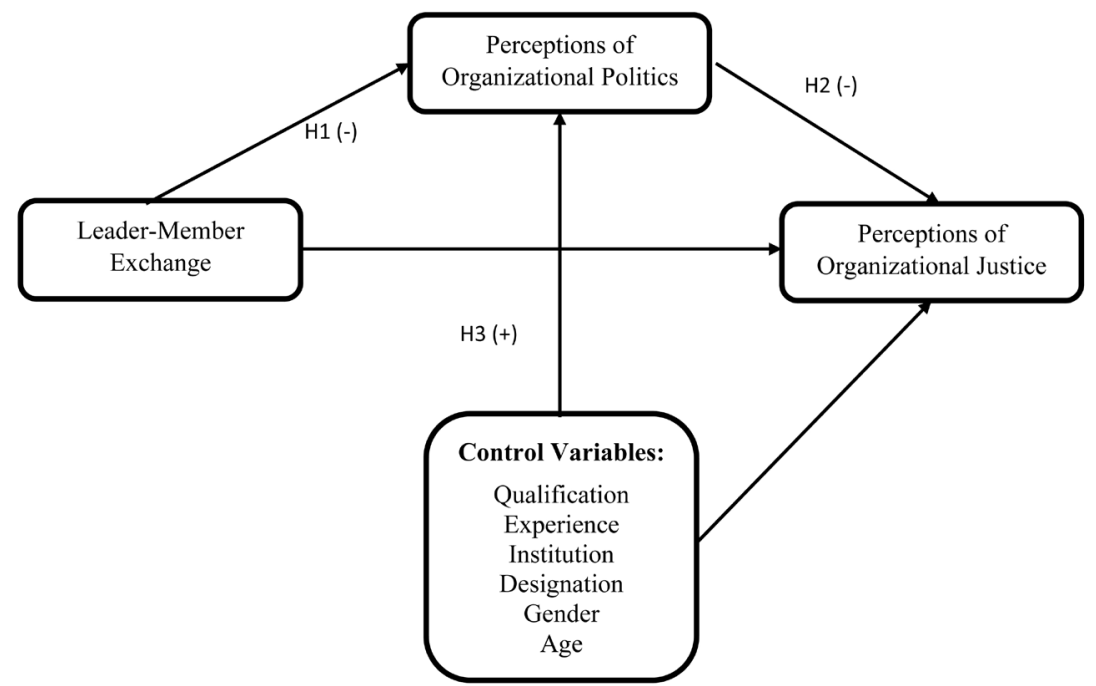

Figure 1. Showing the proposed conceptual framework. 
of 9 - 39 years. The present study used Structural Equation Modeling (SEM) for analyzing the proposed relationships among the variables. According to [62], for ensuring the representativeness and maintaining the accuracy of estimations, SEM requires relatively large sample size. Different researchers have suggested that sample size should be determined in term of number of subjects per estimated parameters in the model [63] [64] [65]. These researchers have proposed a minimum of five cases per estimated parameters. There are 47 distinct parameters in the proposed conceptual model and data was collected from 493 respondents which show the adequacy of the sample size in the proposed model.

\subsection{Measures}

\subsubsection{Leader-Member Exchange}

In order to measure the quality of leader-member exchange, scale by [66] was used. It is a twelve item multi-dimensional scale measuring the quality of relationship between subordinate and supervisor with four constructs namely loyalty, affect, contribution and professional respect. Each construct consist of three statements. High score indicated that employee (faculty member) favorably perceive high quality relationship with their supervisor (HOD). In the present study despite having multiple-dimensions in the scale, the researcher treated LMX as one factor. The reason for such consideration is the high degree of correlation among the different construct of LMX which is also depicted by Graen, G. B., \& Uhl-Bien, M. [67]. The scale was measure on five-point Likert scale anchoring form strongly disagree (1) to strongly agree (5). The Cronbach's alpha of this scale was 0.84 .

\subsubsection{Perceptions of Organizational Justice}

Perception of Organizational Justice was measure with the research instrument developed by Colquitt, J. A. [52]. This research instrument consists of four constructs namely Distributive justice, Procedural justice, Interpersonal justice and Informational justice. Distributive justice was assessed by four items. Procedural justice was assessed by seven items that asked individuals to refer to the procedures used to determine things that affect them on their job, like pay raises, promotions, opportunities for training and so on. Interpersonal justice was assessed by four items and Informational Justice was assessed by five items. The scale was measure on five-point Likert scale anchoring form strongly disagree (1) to strongly agree (5). Cronbach's alpha for distributive justice was 0.85 , for procedural justice was 0.88 , for interpersonal justice was 0.87 and for informational justice was 0.88 .

\subsubsection{Perceptions of Organizational Politics}

Perception of organizational politics was measured in terms of General Political Behaviour, Go Along to Get Ahead, Pay \& Promotion Policy. The perceptions of organizational politics was measured with the help of research instrument developed by Kacmar, K. M., \& Carlson, D. S. [68], Perception of Organizational 
Politics Scale (POPS). The scale consist of fifteen statements, out of which two statements measure general political behavior for example "Faculty members in this institution attempt to build themselves up by letting down others", seven statements measure go along to get ahead construct for example "Faculty members are encouraged to speak out frankly even when they are critical of well-established ideas" and six statements measures pay \& promotion policy construct for example "Since I have worked in this department, I have never seen the pay and promotion policies applied politically". The scale was measure on five-point likert scale anchoring form strongly disagree (1) to strongly agree (5). The wordings of the statements were slightly modified in context of the present study. The Cronbach's alpha of this scale was 0.91 .

\subsection{Control Variables}

In the proposed structural model, educational qualification, job experience, institution in which employee works, designation of the employee, gender and age we controlled [69]-[74].

\subsection{Data Analysis}

In order to analyses the proposed structural model, the researcher used SEM in AMOS 18.0 version. The structural model assign the causal relationships between one endogenous variable (perceptions of organizational politics); four consequence variables (distributive justice, procedural justice, interpersonal justice and informational justice) and five control variables (gender, institute, educational qualification, designation, experience). Furthermore, in order to test the mediating effect of perceptions of organizational politics on the proposed relationships, the researcher used bootstrapping technique with bias-corrected confidence interval at $95 \%$ confidence level.

\section{Results}

Preliminary Analysis

As mentioned before, the research design of the present was cross-sectional in nature and further the data was collected through self-reported method. Therefore, there might be an issue of common method biasness in the study [75]. So, in order to mitigate the effect of common method biasness, the questionnaires were selected in such a way that it included negative worded statements. But in order to test it statistically, the researcher performed one of the most acceptable methods of eliminating common method variance, that is, Harman's single factor analysis. Following the recommendations suggested by [75], an exploratory factor analysis by including all the statements from all the three different scales used in the study to see whether any single factor contributes exceptionally large variance in the factor analysis or not. Results of the exploratory factor analysis result into 11 different factors, but none of the factor explain the variance to a large extent. This shows that there was no issue of common method variance in 
the present study.

Further, confirmatory factor analysis was performed with the help of AMOS 18. Result of the CFA shows that four-factor measure of perceptions of organizational justice (procedural, distributive, interpersonal and informational justice: $\chi^{2}=273.269$, D.F. $=127, \mathrm{p}>0.001$, CMIN/D.F $=2.152 \leq 3$ [76], GFI $=0.944 \geq$ 0.80 [77], CFI $=0.972 \geq 0.90$ [76], $\mathrm{RMR}=0.044 \leq 0.10$ [78], AGFI $=0.925 \geq 0.80$ [79], RMSEA $=0.048 \leq 0.08$ [80]) has better model fit than one-factor measure of perceptions of organizational justice $\left(\chi^{2}=304.407\right.$, D.F. $=129, \mathrm{p}>0.001$, CMIN/D.F $=2.360 \leq 3$ [76], GFI $=0.938 \geq 0.80$ [77], CFI $=0.966 \geq 0.90$ [76], $\mathrm{RMR}=0.055 \leq 0.10$ [78], AGFI $=0.918 \geq 0.80$ [79], RMSEA $=0.053 \leq 0.08$ [80]) in which procedural, distributive, interpersonal and informational justices are combined. Therefore, a decision to go with four-factor model of perceptions of organizational justice was taken.

Furthermore, results of the CFA were also utilized for determining the discriminant validity of different factors. The hypothesized six-factor model depicted better model fit $\left(\chi^{2}=1665.33\right.$, D.F. $=1006, \mathrm{p}>0.001, \mathrm{CMIN} / \mathrm{D} . \mathrm{F}=1.65$ $\leq 3$ [76], GFI $=0.88 \geq 0.80$ [77], CFI $=0.96 \geq 0.90$ [76], RMSEA $=0.03 \leq 0.08$ [80]) than competing models. Results of Table 1 show the results of different model fit indices of all the possible conceptual models. Results depicted that Model 1 (Hypothesized Model) was significantly superior than the model fit indices of model $2\left(\Delta \chi^{2}\right.$ from Model $\left.1=325.34, \mathrm{p}<0.001\right)$. In the similar manner, model 1 showed better results than model $3\left(\Delta \chi^{2}\right.$ from Model $1=$ 500.18, $\mathrm{p}<0.001)$. Furthermore, results of Table 1 show that model 1 depicts better results than models number four, five, six, seven, eight and finally nine. Therefore, a decision was taken to retain model 1 with six factors.

Table 2 represents the descriptive statistics, inter-construct correlation and

Table 1. Comparison of alternative model.

\begin{tabular}{cccccccccc}
\hline Model & Description & $\chi^{2}$ & $\mathrm{df}$ & $\chi^{2} / \mathrm{df}$ & CFI & GFI & RMSEA & $\begin{array}{c}\Delta \chi^{2} \text { from } \\
\text { Model 1 }\end{array}$ & $\Delta \mathrm{df}$ \\
\hline Model 1 & Hypothesized & 1665.33 & 1006 & 1.65 & 0.96 & 0.88 & 0.03 & & \\
Model 2 & Five Factor $^{\mathrm{a}}$ & 1990.67 & 1011 & 1.97 & 0.94 & 0.86 & 0.04 & $325.34^{*}$ & 5 \\
Model 3 & Four Factor $^{\mathrm{b}}$ & 2165.51 & 1014 & 2.14 & 0.93 & 0.85 & 0.05 & $500.18^{*}$ & 8 \\
Model 4 & Four Factor $^{\mathrm{c}}$ & 2136.72 & 1014 & 2.11 & 0.93 & 0.85 & 0.05 & $471.39^{*}$ & 8 \\
Model 5 & Four Factor $^{\mathrm{d}}$ & 2145.98 & 1014 & 2.12 & 0.93 & 0.85 & 0.05 & $480.65^{*}$ & 8 \\
Model 6 & Four Factor $^{\mathrm{e}}$ & 2158.66 & 1014 & 2.13 & 0.93 & 0.85 & 0.05 & $493.33^{*}$ & 8 \\
Model 7 & Three Factor $^{\mathrm{f}}$ & 1706.17 & 1014 & 1.68 & 0.96 & 0.88 & 0.04 & $40.84^{*}$ & 8 \\
Model 8 & Two Factor $^{\mathrm{g}}$ & 1974.44 & 1016 & 1.94 & 0.94 & 0.86 & 0.04 & $309.11^{*}$ & 10 \\
Model 9 & One Factor $^{\mathrm{h}}$ & 2195.76 & 1017 & 2.16 & 0.93 & 0.84 & 0.05 & $530.43^{*}$ & 11 \\
\hline
\end{tabular}

Notes: ${ }^{a}$ Five Factor: LMX and POP combined; ${ }^{b}$ Four Factor: LMX, POP and procedural justice combined; 'Four Factor: LMX, POP and distributive justice combined; ' Four Factor: LMX, POP and interpersonal jus-

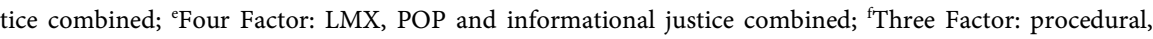
distributive, interpersonal and informational combined; ${ }^{\mathrm{g}} \mathrm{Two}$ Factor: LMX and POP combined, and POJ as one factor; ${ }^{*} \mathrm{p}<0.001$. 
reliability coefficient. Results of Table 2 depicted that perception of organizational politics was positively correlated with leader-member exchange $(r=0.31$, $\mathrm{p}<0.01)$, informational justice $(r=0.14, \mathrm{p}<0.01)$, interpersonal justice $(r=$ $0.21, \mathrm{p}<0.01)$, procedural justice $(r=0.15, \mathrm{p}<0.01)$, and distributive justice $(r=$ $0.11, \mathrm{p}<0.05)$. Further, results showed that leader-member exchange was significantly positively associated with all the four dimensions of perceptions of organizational justice, that is, informational justice $(r=0.52, \mathrm{p}<0.01)$, interpersonal justice $(r=0.47, \mathrm{p}<0.01)$, procedural justice $(r=0.50, \mathrm{p}<0.01)$, and distributive justice $(r=0.43, \mathrm{p}<0.05)$. Additionally, informational justice was positively associated with interpersonal justice $(r=0.73, \mathrm{p}<0.01)$, procedural justice $(r=0.72, \mathrm{p}<0.01)$, and distributive justice $(r=0.57, \mathrm{p}<0.01)$. Apart from this, results also depicted that interpersonal justice was positively related with procedural justice $(r=0.58, \mathrm{p}<0.01)$ and distributive justice $(r=0.56, \mathrm{p}<0.01)$. Procedural justice was significantly positively correlated with distributive justice $(r=$ $0.72, \mathrm{p}<0.01)$. Finally, results also showed that all the values of Cronbach alpha coefficient is more than the minimum cut-off criterion value of 0.7 [81].

In order to test the test the proposed hypothesis, the present study make use of AMOS 18 to determine the relationship between leader-member exchange and perceptions of organizational politics, leader-member exchange and four dimensions of perceptions of organizational justice, perceptions of organizational politics and four dimensions of perceptions of organizational justice by controlling age, gender, designations, educational qualification, experience and institution in which employees are working. Results of Table 3 render direct relationships between the examined variables. Critical ratio (CR) of the regression estimate was used to check the level of significance [82]. Critical ratio equal to or more than 2.58 indicate a significance level at 0.01 ; whereas, if the value of critical ratio is equal to or more than 1.96 but less than 2.58 then it indicates a significance level at 0.05 . Results of Table 3 render significant and positive relationship ( $\beta=0.311, \mathrm{CR}=7.27$ ) relationship between the quality of leader-member exchange and perceptions of organizational politics such that in-group members perceives high level of organizational politics whereas employees who are part of out-group member have shown lower levels of perceptions of organizational politics. Further, results showed that perceptions of

Table 2. Descriptive statistics, correlation and reliability.

\begin{tabular}{ccccccccc}
\hline & Mean & SD & 1 & 2 & 3 & 4 & 5 & 6 \\
\hline POP & 2.27 & 0.72 & $(0.91)$ & & & & & \\
LMX & 3.55 & 0.75 & $0.31^{* *}$ & $(0.84)$ & & & & \\
Informational & 2.64 & 0.69 & $0.14^{* *}$ & $0.52^{* *}$ & $(0.88)$ & & & \\
Interpersonal & 3.23 & 0.78 & $0.21^{* *}$ & $0.47^{* *}$ & $0.73^{* *}$ & $(0.87)$ & & \\
Procedural & 2.59 & 0.62 & $0.15^{* *}$ & $0.50^{* *}$ & $0.72^{* *}$ & $0.58^{* *}$ & $(0.88)$ & \\
Distributive & 3.23 & 0.69 & $0.11^{*}$ & $0.43^{* *}$ & $0.57^{* *}$ & $0.56^{* *}$ & $0.72^{* *}$ & $(0.85)$ \\
\hline
\end{tabular}

Source: Author's Compilation. Note: ${ }^{* *} \mathrm{p}<0.01$; ${ }^{\star} \mathrm{p}<0.05$. Off-diagonal values represent reliability coefficients. 
Table 3. Results of the regression estimates.

\begin{tabular}{ccccc}
\hline Hypotheses & Relationship & Standardized Estimate & C. $\mathbf{R}$ & Hypothesis Accepted \\
\hline H1 & LMX $\rightarrow$ POP (-) & 0.311 & $7.27^{* * *}$ & NO \\
H2 (a) & POP $\rightarrow$ PJ (-) & -0.013 & -0.32 & YES \\
H2 (b) & POP $\rightarrow$ DJ (-) & -0.033 & -0.77 & YES \\
H2 (c) & POP $\rightarrow$ INF (-) & -0.028 & -0.71 & YES \\
H2 (d) & POP $\rightarrow$ INT (-) & 0.068 & 1.64 & NO \\
H3 (a) & LMX $\rightarrow$ PJ (+) & 0.507 & $12.51^{* * *}$ & YES \\
H3 (b) & LMX $\rightarrow$ DJ (+) & 0.449 & $10.60^{* * *}$ & YES \\
H3 (c) & LMX $\rightarrow$ INF (+) & 0.538 & $13.59^{* * *}$ & YES \\
H3 (d) & LMX $\rightarrow$ INT (+) & 0.445 & $10.74^{* * *}$ & YES \\
\hline
\end{tabular}

Notes: ${ }^{\star * \star} \mathrm{p}$-value $<0.01 ;{ }^{* *} \mathrm{p}$-value $<0.05$

organizational politics was negatively associated with procedural, distributive and informational justice and positively related with interpersonal justice. But these relationships were not statistically significant. Therefore, $\mathrm{H} 2$ was not accepted. Additionally, results of Table 3 also depicted that the quality of leader-member exchange has significant and positive relationship with procedural justice $(\beta=0.507, \mathrm{CR}=12.51)$, distributive justice $(\beta=0.449, \mathrm{CR}=10.60)$, informational justice $(\beta=0.538, C R=13.59)$ and interpersonal justice $(\beta=0.445$, $\mathrm{CR}=10.74)$.

Results of the bootstrapped mediation analysis (Table 4) revealed that perception of organizational politics fully mediates the relationship between leader-member exchange and perceptions of procedural justice. In the similar manner, perception of organizational politics fully mediates the relationship between leader-member exchange and perceptions of distributive justice. In addition to this, results of the mediation analysis depicted that the relationship between leader-member exchange and perception of interpersonal justice was partially mediated through perceptions of organizational politics. Finally, results manifested that perceptions of organizational politics partially mediates the relationship between the quality of leader-member exchange and perceptions of informational justice among the employees.

\section{Discussion}

The purpose of the present study was to examine the mediating role of perceptions of organizational politics on the relationship between the quality of leader-member exchange and four dimensions of perceptions of organizational justice. Results of the study showed positive relationship between the quality of leader-member exchange and perceptions of organizational politics. It means that the employee who perceives high quality relationship with their leader has high level of perceptions of organizational politics. On the other hand, employees who are part of out-group they perceive lower degree of perceptions of 
Table 4. Results of the Bootstrapped Mediation.

\begin{tabular}{lccccc}
\hline \multicolumn{1}{c}{ Mediating Relationship } & Estimate $^{*}$ & p-value & Estimate $^{* *}$ & p-value & $\begin{array}{c}\text { Type of } \\
\text { Mediation }\end{array}$ \\
\hline $\begin{array}{l}\text { Leader-member exchange towards } \\
\text { procedural justice through } \\
\text { perceptions of organizational politics }\end{array}$ & -0.004 & 0.767 & 0.507 & 0.019 & Full \\
$\begin{array}{l}\text { Leader-member exchange towards } \\
\text { distributive justice through }\end{array}$ & -0.010 & 0.413 & 0.449 & 0.008 & Full \\
$\begin{array}{l}\text { perceptions of organizational politics } \\
\text { Leader-member exchange towards }\end{array}$ & & & & & \\
$\begin{array}{l}\text { interpersonal justice through } \\
\text { perceptions of organizational politics }\end{array}$ & 0.021 & 0.069 & 0.445 & 0.010 & Partial \\
$\begin{array}{l}\text { Leader-member exchange towards } \\
\text { informational justice through } \\
\text { perceptions of organizational politics }\end{array}$ & -0.009 & 0.425 & 0.538 & 0.006 & Partial \\
\hline
\end{tabular}

Note: ${ }^{\star S t a n d a r d i z e d ~ I n d i r e c t ~ E f f e c t s ; ~}{ }^{*}$ Standardized Direct Effects.

organizational politics. The probable reason for such kind of results might be that the employees who are part of in-group, they are more aware about the political mechanism which is prevailing within the organization. The same results were demonstrated by Andrews, M. C. \& Kacmar, K. M. [38], in which results depicted positive relationship between the perceptions of organizational politics and the quality of leader-member exchange. They suggested that individual who is part of high quality relationship will have "in-the-know" regarding the machinations of organizational politics. Furthermore, Davis, W. D. \& Gardner, W. L. [41] argued that leadership is progressively seen as political process as organizational perspectives of politics gain acceptance due to the changing organizational environment. Many researchers have commenced to shun the belief that organizational politics should be considered as negative and unwanted, but still it is usually considered as negative aspect of organizational environment. This study endeavored a new insight how leader-member exchange perspectives and attributions contribute in eliciting negative affective and cognitive responses to the perceptions of political environment. The study argues that quality of LMX enhances one's understanding of these organizational reactions and processes in a political environment. Study also explored how quality of LMX and attributional processes impact the perceptions of organizational politics and organizational cynicism. On the contrary, researchers like Ferris et al. [40] [42] [43] [44] have demonstrated a significant negative relationship between perceptions of organizational politics and the LMX relationship. Results of the present study also demonstrated that perception of organizational politics has negative relationship with three types of perceptions of organizational justice (procedural, distributive and informational justice) whereas interactional justice is positively associated with perceptions of organizational politics. In the similar manner [34] [36] [37] [38] demonstrated the inverse relationship between perceptions of organizational politics and perceptions of organizational justice. In one such study, 
Byrne, Z. [35] tested the proposition that interactional and procedural fairness mitigates the negative effects of perceived organizational politics on organizational citizenship behavior, turnover intentions and in-role job performance. Results of the study revealed that perceived high levels of procedural justice significantly moderate the relationship between covert political behavior (go along to get ahead) and turnover intentions but not with general political behavior (overt) and turnover intentions. However, the relationship between covert behavior and interactional justice was in opposite direction. Neither the perceptions of interactional nor the perceptions of procedural justice moderated the perceptions of two types of organizational politics on OBC beneficial to supervisors and supervisors rated job performance. Study finally depicted that both interactional and procedural justice had moderating effects on covert but not on overt political behavior. Furthermore, results of the present study depicted that the quality of leader-member exchange has positive effect on the employee's perception regarding organizational justice [17] [30] [31] [32] [59]. On the contrary, Andrews, M. C. \& Kacmar, K. M. [38] found that there is no relationship between leader-member exchange and the perceptions of distributive justice. Nevertheless, Wayne, S. J. et al. [83] demonstrated a significant positive relationship between the quality of relationship between employee-leader and the perceptions of distributive justice among employees.

\section{Practical Implications}

The results of the present study render that high quality leader-member exchange at one hand leads to high perceptions of organizational politics and on other hand it results in high perception of employees regarding organizational justice. Furthermore, high perceptions of organizational politics results in lower level of perceptions of organizational justice. Therefore, the best approach for the managers to reduce the negative effects of high perceptions of organizational politics will be by giving a more detailed conceptualization of the dual nature of perceptions of organizational politics [84]. The darker side of the organizational politics has several harmful effects for the organization such as reduced organizational effectiveness and efficiency which further affects the employees [43] [85]. Results of the meta-analysis revealed a strong empirical evidence that high perceptions of organizational politics results in lower levels of task performance, organizational citizenship behavior, organizational commitment, job satisfaction and at the same time it results in higher levels of psychological strain [39] [86]. However, there is also a brighter side of organizational politics which suggest that high levels of organizational politics results in high job commitment [87], continuance commitment [88], high job involvement [40] and lower turnover intension [89]. Therefore, the managerial skills and better understanding of the concept of organizational politics of the manager plays a vital role. As manager can utilize the political behaviors of the employees in such a way that may lead to better and positive organizational consequences. From the point of view of the 
results of the present study, for a more positive perception of organizational justice among the employees a leader should develop a high quality relationship with more employees by limiting the usage of more political behavior within the organization. Managers should create such a working environment within the organization that majority of the employees can perceive that they are also part of in-group. A manager who knows how to manipulate the perceptions of employees can lead to more desirable organizational outcomes and at the same time this would help in preventing the negative organizational outcomes. This high quality relationship will further benefit the employees as leader will exchange personal and positional resources (inside information, influence in decision making, task assignment, job latitude, support, and attention) in return for subordinate's performance on unstructured tasks [90]. As a result, research shows mutual trust, positive support, informal interdependencies, greater job attitude, common bonds, open communication, high degree of autonomy, satisfaction, and shared loyalty exist [67] [91] [92]. Previous research has shown that employees reciprocate this relationship by showing extra-role behavior for the organization and increased job satisfaction [20] [83] [93]. The realization of the factors that affects the perceptions of organizational politics will not only help an employer to understand their employees properly but also help the supervisor to understand the factors that affects the perceptions of organizational politics which can ultimately help the supervisor to exert some control over the politically charged environment. This will further help managers in altering the perceptions of employees and take corrective measures to reduce the negative impact of organizational politics. For instance, a supervisor in order to mitigate the negative effects of perceptions of organizational politics can provide timely and appropriate information about decisions that have direct impact on the employees. Additionally, a manager can include the employees in decision making process also in order to reduce the negative perceptions of organizational politics. These steps will help the employees to better understand the decision making process of the organization which will ultimately lead to have a harmonious relationship between leader and member.

\section{Limitation of the Study}

Despite the useful information provided by the present study, there are some limitations which must be taken into considerations while making generalizations of the results. The first limitation was pertaining to the way of collecting the data. A self-reported method was adopted to collect the data from the respondents. This type of data collection method can cause an issue of common method variance. However, Spector, P. E. [94] has proposed that common method variance is of less concern in those studies which make use of a well-designed multi-statement validated questionnaire. In the present study, researcher has used a well-designed and validate questionnaire. Second limitation is related to the cross-sectional design, which precludes strong causal relationship among the va- 
riables [95]. That is, we cannot study the causal relationship between the work locus of control, perceptions of organizational politics and perceptions of organizational justice. However, according to Serlin, R. C. [96] this limitation is offset to some extent by making predictions based on a priori theory which enables us to make generalizations to the theory but not to the population. In order to make a causal inference, a researcher should go for a longitudinal study.

\section{Conflicts of Interest}

The authors declare no conflicts of interest regarding the publication of this paper.

\section{References}

[1] Lind, E.A. and Tyler, T.R. (1988) The Social Psychology of Procedural Justice. Plenum Press, New York. https://doi.org/10.1007/978-1-4899-2115-4

[2] Cohen-Charash, Y. and Spector, P.E. (2001) The Role of Justice in Organizations: A Meta-Analysis. Organizational Behavior and Human Decision Processes, 86, 278-321. https://doi.org/10.1006/obhd.2001.2958

[3] Leow, K. and Khong, K. (2009) Organizational Commitment: The Study of Organizational Justice and Leader Member Exchange (LMX) among Auditors in Malaysia. International Journal of Business and Information, 4, 161-198.

[4] Omari, S., K'obonyo, P. and Kidombo, H. (2012) The Moderating Role of Organizational Justice on the Relationship between Age, Locus of Control and Employee Outcomes. DBA Africa Management Review, 2, 42-54.

[5] Alexander, S. and Ruderman, M. (1987) The Role of Procedural and Distributive Justice in Organizational Behavior. Social Justice Research, 1, 177-198. https://doi.org/10.1007/BF01048015

[6] Scott, B.A. and Colquitt, J.A. (2007) Are Organizational Justice Effects Bounded by Individual Differences? An Examination of Equity Sensitivity, Exchange Ideology, and the Big Five. Group \& Organization Management, 32, 290-325. https://doi.org/10.1177/1059601106286877

[7] Katrinli, A., Atabay, G., Gunay, G. and Cangarli, B. (2010) Perception of Organizational Politics and LMX: Linkages in Distributive Justice and Job Satisfaction. African Journal of Business Management, 4, 3110-3121.

[8] Hom, P.W., Griffeth, R.W. and Sellaro, C.L. (1984) The Validity of Mobley's (1977) Model of Employee Turnover. Organizational Behavior and Human Performance, 34, 141-174. https://doi.org/10.1016/0030-5073(84)90001-1

[9] Daileyl, R.C. and Kirk, D.J. (1992) Distributive and Procedural Justice as Antecedents of Job Dissatisfaction and Intent to Turnover. Human Relations, 45, 305-317. https://doi.org/10.1177/001872679204500306

[10] Hendrix, W.H., Robbins, T., Miller, J. and Summers, T.P. (1998) Effects of Procedural and Distributive Justice on Factors Predictive of Turnover. Journal of Social Behavior and Personality, 13, 611-632.

[11] Fields, D., Pang, M. and Chiu, C. (2000) Distributive and Procedural Justice as Predictors of Employee Outcomes in Hong Kong. Journal of Organizational Behavior, $21,547-562$. https://doi.org/10.1002/1099-1379(200008)21:5<547::AID-JOB41>3.0.CO;2-I

[12] Loi, R., Ngo, H.-Y. and Foley, S. (2006) Linking Employees' Justice Perceptions to Organizational Commitment and Intention to Leave: The Mediating Role of Per- 
ceived Organizational Support. Journal of Occupational and Organizational Psychology, 79, 101-120. https://doi.org/10.1348/096317905X39657

[13] Konovsky, M.A. and Cropanzano, R. (1991) Perceived Fairness of Employee Drug Testing as a Predictor of Employee Attitudes and Job Performance. Journal of Applied Psychology, 76, 698-707. https://doi.org/10.1037/0021-9010.76.5.698

[14] Konovsky, M.A. (2000) Understanding Procedural Justice and Its Impact on Business Organizations. Journal of Management, 26, 489-511. https://doi.org/10.1177/014920630002600306

[15] Gilliland, S.W. (1994) Effects of Procedural and Distributive Justice on Reactions to a Selection System. Journal of Applied Psychology, 79, 691-701. https://doi.org/10.1037/0021-9010.79.5.691

[16] Moorman, R.H. (1991) Relationship between Organizational Justice and Organizational Citizenship Behaviour: Do Fairness Perceptions Influence Employee Citizenship? Journal of Applied Psychology, 76, 845-855. https://doi.org/10.1037/0021-9010.76.6.845

[17] Manogran, P., Stauffer, J. and Conlon, E.J. (1994) Leader-Member Exchange as a Key Mediating Variable between Employees' Perceptions of Fairness and Organizational Citizenship Behaviour. National Academy of Management Meeting Proceedings, 1994, 249-267.

[18] Konovsky, M.A. and Pugh, S.D. (1994) Citizenship Behaviour and Social Exchange. Academy of Management Journal, 37, 656-669.

[19] Iqbal, H., Aziz, U. and Tasawar, A. (2012) Impact of Organizational Justice on Organizational Citizenship Behavior: An Empirical Evidence from Pakistan. World Applied Sciences Journal, 19, 1348-1354.

[20] Aggarwal, A. and Singh, R. (2016) Exploring the Nomological Network of Organizational Citizenship Behavior: A Review of Dimensions, Antecedents and Consequences. IUP Journal of Organizational Behavior, 15, 16-39.

[21] Masterson, S., Lewis, K., Goldman, B. and Taylor, M. (2000) Integrating Justice and Social Exchange: The Differing Effects of Fair Procedures and Treatment on Work Relationships. Academy of Management Journal, 43, 738-748.

[22] Austin, W. and Walster, E. (1974) Reactions to Confirmations and Disconfirmations of Expectancies of Equity and Inequity. Journal of Personality and Social Psychology, 30, 208-216. https://doi.org/10.1037/h0036622

[23] Greenberg, J. (1996) The Quest for Justice on the Job: Essays and Experiments. Sage Publications, Thousand Oaks.

[24] Greenberg, J. (1990) Organizational Justice: Yesterday, Today, and Tomorrow. Journal of Management, 16, 399-432. https://doi.org/10.1177/014920639001600208

[25] Folger, R.G. and Cropanzano, R. (1998) Organizational Justice and Human Resource Management. Vol. 7, Sage Publications, Thousand Oaks.

[26] Blau, P.M. (1964) Exchange and Power in Social Life. John Wiley \& Sons, New York.

[27] Pillai, R., Schriesheim, C.A. and Williams, E.S. (1999) Fairness Perceptions and Trust for Transformational and Transactional Leadership: A Two-Sample Study. Journal of Management, 25, 897-933. https://doi.org/10.1177/014920639902500606

[28] Moorman, R.H., Blakely, G.L. and Niehoff, B.P. (1998) Does Perceived Organizational Support Mediate the Relationship between Procedural Justice and Organizational Citizenship Behaviour? Academy of Management Journal, 41, 351-357. https://doi.org/10.5465/256913 
[29] Van Olffen, W. and De Cremer, D. (2007) Who Cares about Organizational Justice? How Personality Moderates the Effects of Perceived Fairness on Organizational Attachment. European Journal of Work and Organizational Psychology, 16, 386-406. https://doi.org/10.1080/13594320701504901

[30] Miller, B.K. and Nicols, K.M. (2008) Politics and Justice: A Mediated Moderation Model. Journal of Managerial Issues, 20, 214-237.

[31] Vecchio, R.P., Griffeth, R.W. and Horn, P.W. (1986) The Predictive Utility of the Vertical Dyad Linkage Approach. Journal of Social Psychology, 126, 617-625. https://doi.org/10.1080/00224545.1986.9713634

[32] Podsakoff, P.M., MacKenzie, S.B., Moorman, R.H. and Fetter, R. (1990) Transformational Leader Behaviors and Their Effects on Followers' Trust in Leader, Satisfaction, and Organizational Citizenship Behaviors. The Leadership Quarterly, 1, 107-142. https://doi.org/10.1016/1048-9843(90)90009-7

[33] Andrews, M., Kacmar, K. and Harris, K. (2009) Got Political Skill? The Impact of Justice on the Importance of Political Skill for Job Performance. Journal of Applied Psychology, 94, 1427-1437. https://doi.org/10.1037/a0017154

[34] Aryee, S., Chen, Z.X. and Budhwar, P.S. (2004) Exchange Fairness and Employee Performance: An Examination of the Relationship between Organizational Politics and Procedural Justice. Organizational Behavior and Human Decision Processes, 94, 1-14. https://doi.org/10.1016/j.obhdp.2004.03.002

[35] Byrne, Z. (2005) Fairness Reduces the Negative Effects of Organizational Politics on Turnover Intentions, Citizenship Behavior and Job Performance. Journal of Business and Psychology, 20, 175-200. https://doi.org/10.1007/s10869-005-8258-0

[36] Amah, O. and Okafor, C. (2008) The Interactive Effect of Organizational Politics in the Justice, Organizational Support and Job Satisfaction Relationships. Asian Journal of Scientific Research, 1, 492-501. https://doi.org/10.3923/ajsr.2008.492.501

[37] Harris, K.J., Andrews, M.C. and Kacmar, K.M. (2007) The Moderating Effects of Justice on the Relationship Between Organizational Politics and Workplace Attitudes. Journal of Business and Psychology, 22, 135-144. https://doi.org/10.1007/s10869-007-9054-9

[38] Andrews, M.C. and Kacmar, K.M. (2001) Discriminating among Organizational Politics, Justice, and Support. Journal of Organizational Behaviour, 22, 347-366. https://doi.org/10.1002/job.92

[39] Chang, C.H., Rosen, C.C. and Levy, P.E. (2009) The Relationship between Perceptions of Organizational Politics and Employee Attitudes, Strain, and Behavior: A Meta-Analytic Examination. Academy of Management Journal, 52, 779-801. https://doi.org/10.5465/amj.2009.43670894

[40] Ferris, G.R. and Kacmar, K.M. (1992) Perceptions of Organizational Politics. Journal of Management, 18, 93-116. https://doi.org/10.1177/014920639201800107

[41] Davis, W.D. and Gardner, W.L. (2004) Perceptions of Politics and Organizational Cynicism: An Attributional and Leader-Member Exchange Perspective. Leadership Quarterly, 15, 439-465. https://doi.org/10.1016/j.leaqua.2004.05.002

[42] Valle, M. and Perrewé, P.L. (2000) Do Politics Perceptions Relate to Political Behaviour? Tests of an Implicit Assumption and Expanded Model. Human Relations, 53, 359-385. https://doi.org/10.1177/0018726700533004

[43] Kacmar, K.M., Bozeman, D.P., Carlson, D.S. and Anthony, W.P. (1999) An Examination of the Perceptions of Organizational Politics Model: Replication and Extension. Human Relations, 52, 383-416. https://doi.org/10.1177/001872679905200305 
[44] Ferris, G.R., Perrewé, P.L. and Douglas, C. (2002) Social Effectiveness in Organizations: Construct Validity and Research Directions. Journal of Leadership and Organizational Studies, 9, 30-55. https://doi.org/10.1177/107179190200900104

[45] Wakabayashi, M., Graen, G.B., Graen, M.R. and Graen, M.G. (1988) Japanese Management Progress: Mobility into Middle Management. Journal of Applied Psychology, 73, 217-228. https://doi.org/10.1037/0021-9010.73.2.217

[46] Liden, R.C. and Graen, G. (1980) Generalizability of the Vertical Dyad Linkage Model of Leadership. Academy of Management Journal, 23, 451-465.

[47] Graen, G., Novak, M.M. and Sommerkamp, P. (1982) The Effects of Leader-Member Exchange and Job Design on Productivity and Satisfaction: Testing a Dual Attachment Model. Organizational Behavior and Human Performance, 30, 109-131. https://doi.org/10.1016/0030-5073(82)90236-7

[48] Scandura, T.A. and Graen, G.B. (1984) Moderating Effects of Initial Leader-Member Exchange Status on the Effects of a Leadership Intervention. Journal of Applied Psychology, 69, 428-436. https://doi.org/10.1037/0021-9010.69.3.428

[49] Erdogan, B., Kraimer, M.L. and Liden, R.C. (2004) Work Value Congruence and Intrinsic Career Success: The Compensatory Roles of Leader-Member Exchange and Perceived Organizational Support. Personnel Psychology, 57, 305-332. https://doi.org/10.1111/j.1744-6570.2004.tb02493.x

[50] Ferris, G.R., Treadway, D.C., Perrewé, P.L., Brouer, R.L., Douglas, C. and Lux, S. (2007) Political Skill in Organizations. Journal of Management, 33, 290-320. https://doi.org/10.1177/0149206307300813

[51] Cropanzano, R. and Greenberg, J. (1997) Progress in Organizational Justice: Tunneling through the Maze. In: Cooper, C. and Robertson, I., Eds., International Review of Industrial and Organizational Psychology, Wiley, New York, 317-372.

[52] Colquitt, J.A. (2001) On the Dimensionality of Organizational Justice: A Construct Validation of a Measure. Journal of Applied Psychology, 86, 386-400. https://doi.org/10.1037/0021-9010.86.3.386

[53] Greenberg, J. (1987) A Taxonomy of Organizational Justice Theories. Academy of Management Review, 12, 9-22. https://doi.org/10.5465/amr.1987.4306437

[54] Cropanzano, R., Bowen, D.E. and Gilliland, S.W. (2007) The Management of Organizational Justice. Academy of Management Perspectives, 21, 34-48. https://doi.org/10.5465/amp.2007.27895338

[55] Latham, G.P. and Pinder, C.C. (2005) Work Motivation Theory and Research at the Dawn of the Twenty-First Century. Annual Review of Psychology, 56, 485-516. https://doi.org/10.1146/annurev.psych.55.090902.142105

[56] Colquitt, J.A., Conlon, D.E., Wesson, M.J., Porter, C. and Ng, K.Y. (2001) Justice at the Millennium: A Meta-Analytic Review of 25 Years of Organizational Justice Research. Journal of Applied Psychology, 86, 425-445. https://doi.org/10.1037/0021-9010.86.3.425

[57] Deutsch, M. (1985) Distributive Justice: A Social-Psychological Perspective. Yale University Press, New Haven.

[58] Colquitt, J.A. (2004) Does the Justice of the One Interact with the Justice of the Many? Reactions to Procedural Justice in Teams. Journal of Applied Psychology, 89, 633-646. https://doi.org/10.1037/0021-9010.89.4.633

[59] Erdogan, B. and Liden, R.C. (2002) Social Exchanges in the Workplace: A Review of Recent Developments and Future Research Directions in Leader-Member Exchange Theory. In: Neider, L.L. and Schriesheim, C.A., Eds., Leadership, Information Age, 
Greenwich, 65-114.

[60] Wang, X., Liao, J., Xia, D. and Chang, T. (2010) The Impact of Organizational Justice on Work Performance: Mediating Effects of Organizational Commitment and Leader-Member Exchange. International Journal of Manpower, 31, 660-677. https://doi.org/10.1108/01437721011073364

[61] Vigoda-Gadot, E. and Dryzin-Amit, Y. (2006) Organizational Politics, Leadership and Performance in Modern Public Worksites: A Theoretical Framework. Handbook of Organizational Politics, 1, 3-15. https://doi.org/10.4337/9781847201874.00007

[62] Schumacker, R.E. and Lomax, R.G. (1996) A Guide to Structural Equations Modeling. Erl-Baum, Hillsdale.

[63] Bagozzi, R.P. and Yi, Y. (1988) On the Evaluation of Structural Equation Models. Journal of the Academy of Marketing Science, 16, 74-94. https://doi.org/10.1007/BF02723327

[64] Hair, J.F., Tatham, R.L., Anderson, R.E. and Black, W. (1998) Multivariate Data Analysis. Prentice-Hall International, London.

[65] Kline, R.B. (1998) Principles and Practice of Structural Equation Modelling. The Guilford Press, New York.

[66] Liden, R.C. and Maslyn, J.M. (1998) Multidimensionality of Leader-Member Exchange: An Empirical Assessment through Scale Development. Journal of Management, 24, 43-72.

[67] Graen, G.B. and Uhl-Bien, M. (1995) Development of Leader-Member Exchange (LMX) Theory of Leadership over 25 Years: Applying a Multi-Level Multi-Domain Perspective. Leadership Quarterly, 6, 219-247. https://doi.org/10.1016/1048-9843(95)90036-5

[68] Kacmar, K.M. and Carlson, D.S. (1997) A Further Validation of the Perceptions of Politics Scale (POPS): A Multiple-Sample Investigation. Journal of Management, 23, 627-658. https://doi.org/10.1177/014920639702300502

[69] Coetzee, M. (2006) The Fairness of Affirmative Action: An Organisational Justice Perspective. Doctoral Dissertation.

[70] Van Prooijen, J.W., Van den Bos, K. and Wilke, H.A. (2004) Group Belongingness and Procedural Justice: Social Inclusion and Exclusion by Peers Affects the Psychology of Voice. Journal of Personality and Social Psychology, 87, 66-79. https://doi.org/10.1037/0022-3514.87.1.66

[71] Van Prooijen, J.W., Van den Bos, K. and Wilke, H.A. (2005) Procedural Justice and Intragroup Status: Knowing Where We Stand in a Group Enhances Reactions to Procedures. Journal of Experimental Social Psychology, 41, 664-676. https://doi.org/10.1016/j.jesp.2004.12.003

[72] Elovainio, M., Kivimaki, M., Vahtere, J., Virtanen, M. and Keltikangas-Jarvinen, L. (2003) Personality as a Moderator in the Relations between Perceptions of Organizational Justice and Sickness Absence. Journal of Vocational Behavior, 63, 379-395. https://doi.org/10.1016/S0001-8791(02)00058-1

[73] Bauer, T. and Green, S. (1996) Development of a Leader-Member Exchange: A Longitudinal Test. Academy of Management Journal, 39, 1538-1567.

[74] Gandz, J. and Murray, V.V. (1980) The Experience of Workplace Politics. Academy of Management Journal, 23, 237-251.

[75] Podsakoff, P.M., MacKenzie, S.B., Lee, J.Y. and Podsakoff, N.P. (2003) Common Method Biases in Behavioral Research: A Critical Review of the Literature and 
Recommended Remedies. Journal of Applied Psychology, 88, 879-903. https://doi.org/10.1037/0021-9010.88.5.879

[76] Hair, J.F., Black, W.C., Babin, B.J. and Anderson, R.E. (2010) Multivariate Data Analysis. Pearson Education Inc., Pearson.

[77] Miles, J. and Shevlin, M. (1998) Effects of Sample Size, Model Specification and Factor Loadings on the GFI in Confirmatory Factor Analysis. Personality and Individual Differences, 25, 85-90. https://doi.org/10.1016/S0191-8869(98)00055-5

[78] Wu, M.L. (2009) Structural Equation Modeling: Amos Operation and Application. Wu-Nan Book Inc., Taipei.

[79] Byrne, B.M. (2001) Structural Equation Modelling with AMOS: Basic Concepts, Applications, and Programming. Lawrence Erlbaum Associates Inc., Mahwah.

[80] Steiger, J.H. (1990) Structural Model Evaluation and Modification: An Interval Estimation Approach. Multivariate Behavioral Research, 25, 173-180. https://doi.org/10.1207/s15327906mbr2502_4

[81] Nunnally, J.C. (1978) Psychometric Theory. McGraw-Hill, New York.

[82] Biswas, S., Giri, V.N. and Srivastava, K.B. (2006) Examining the Role of HR Practices in Improving Individual Performance and Organizational Effectiveness. Management and Labour Studies, 31, 111-133. https://doi.org/10.1177/0258042X0603100202

[83] Wayne, S.J., Shore, L.M., Bommer, W.H. and Tetrick, L.E. (2002) The Role of Fair Treatment and Rewards in Perceptions of Organizational Support and Leader-Member Exchange. Journal of Applied Psychology, 87, 590-598. https://doi.org/10.1037/0021-9010.87.3.590

[84] Johnson, L.U., Rogers, A., Stewart, R., David, E.M. and Witt, L.A. (2017) Effects of Politics, Emotional Stability, and LMX on Job Dedication. Journal of Leadership and Organizational Studies, 24, 121-130. https://doi.org/10.1177/1548051816656004

[85] Mintzberg, H. (1983) Power in and around Organizations. Vol. 142, Prentice-Hall, Englewood Cliffs.

[86] Miller, B.K., Rutherford, M.A. and Kolodinsky, R.W. (2008) Perceptions of Organizational Politics: A Meta-Analysis of Outcomes. Journal of Business and Psychology, 22, 209-222. https://doi.org/10.1007/s10869-008-9061-5

[87] Cropanzano, R., Howes, J.C., Grandey, A.A. and Toth, P. (1997) The Relationship of Organizational Politics and Support to Work Behaviors, Attitudes, and Stress. Journal of Organizational Behavior, 18, 159-180. https://doi.org/10.1002/(SICI)1099-1379(199703)18:2<159::AID-JOB795>3.0.CO;2$\underline{\mathrm{D}}$

[88] Randall, M.L., Cropanzano, R., Bormann, C.A. and Birjulin, A. (1999) Organizational Politics and Organizational Support as Predictors of Work Attitudes, Job Performance, and Organizational Citizenship Behavior. Journal of Organizational Behavior, 20, 159-174. https://doi.org/10.1002/(SICI)1099-1379(199903)20:2<159::AID-JOB881>3.0.CO;2$\underline{7}$

[89] Larwood, L., Wright, T.A., Desrochers, S. and Dahir, V. (1998) Extending Latent Role and Psychological Contract Theories to Predict Intent to Turnover and Politics in Business Organizations. Group and Organizational Management, 23, 100-123. https://doi.org/10.1177/1059601198232002

[90] Graen, G. and Cashman, J.F. (1975) A Role Making Model in Formal Organizations: A Developmental Approach. In: Hung, J.G. and Larson, L.L., Eds., Leadership Fron- 
tiers, Kent State University Press, Kent, 143-165.

[91] Dansereau, F., Graen, G. and Haga, W.J. (1975) A Vertical Dyad Linkage Approach to Leadership within Formal Organizations-A Longitudinal Investigation of the Role Making Process. Organizational Behaviour and Human Performance, 13, 46-78. https://doi.org/10.1016/0030-5073(75)90005-7

[92] Dienesch, R.M. and Liden, R.C. (1986) Leader-Member Exchange Model of Leadership: A Critique and Further Development. Academy of Management Review, 11, 618-634. https://doi.org/10.5465/amr.1986.4306242

[93] Niehoff, B.P. and Moorman, R.H. (1993) Justice as a Mediator of the Relationship between Methods of Monitoring and Organizational Citizenship Behavior. Academy of Management Journal, 36, 527-556.

[94] Spector, P.E. (1987) Method Variance as an Artifact in Self-Reported Affect and Perceptions at Work: Myth or Significant Problem? Journal of Applied Psychology, 72, 438-443. https://doi.org/10.1037/0021-9010.72.3.438

[95] Pedhazur, E.J. and Schmelkin, L.P. (2013) Measurement, Design, and Analysis: An Integrated Approach. Psychology Press, Hove.

[96] Serlin, R.C. (1987) Hypothesis Testing, Theory Building, and the Philosophy of Science. Journal of Counseling Psychology, 34, 365-371.

https://doi.org/10.1037/0022-0167.34.4.365 